\title{
The Potential Use of Natural Clinoptilolite Zeolite for Crude Oil Spill Removal from Sea Water
}

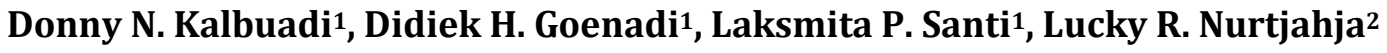 \\ ${ }^{1}$ Indonesian Research Institute for Biotechnology and Bioindustry, Bogor, Indonesia \\ ${ }^{2} \mathrm{PT}$ Minerindo Trifa Buana, Jakarta, Indonesia \\ Email: laksmita.santi@gmail.com
}

How to cite this paper: Kalbuadi, D.N., Goenadi, D.H., Santi, L.P. and Nurtjahja, L.R. (2019) The Potential Use of Natural Clinoptilolite Zeolite for Crude Oil Spill Removal from Sea Water. Journal of Minerals and Materials Characterization and Engineering, 7, 446-453.

https://doi.org/10.4236/jmmce.2019.76031

Received: September 28, 2019

Accepted: November 18, 2019

Published: November 21, 2019

Copyright $\odot 2019$ by author(s) and Scientific Research Publishing Inc. This work is licensed under the Creative Commons Attribution International License (CC BY 4.0). http://creativecommons.org/licenses/by/4.0/

\begin{abstract}
Accidental spillage or drainage from land of crude oil to the marine environment will potentially cause serious damage to the environment and marine life. Many efforts have been focused on the use of most efficient adsorbent to remove the oil and/or oil-decomposing agent from the water. The current study was aimed at to evaluate the most abundantly-available natural zeolite dominated by clinoptilolite mineral and pronounced molecular sieve characteristics as crude oil spill removal in sea water. Bayah-originated zeolite was characterized by using X-ray diffraction (XRD) analysis, pore distribution and average size, gas sorption capacity, and scanning electron microscopy (SEM). A laboratory experiments were conducted by reacting a 100 -mesh zeolite with and without microbial enrichment to crude oil in a $250 \mathrm{~mL}$ sea water $(3.7 \% \mathrm{NaCl}$ and $\mathrm{pH} 6.7) \mathrm{jar}$ at different oil/zeolite ratios, i.e. $50 \%, 100 \%, 200 \%$, and $400 \%(\mathrm{v} / \mathrm{w})$ with three replicates. Observations were made on the stability of zeolite-oil mixture for one week, the weight of zeolite mixed with oil, the oil adsorbed by the zeolite, and free oil after 24-hrs settling. The results indicate that zeolite has highly potential as crude oil adsorbent and the highest oil sorption obtained at zeolite/oil ratio of 1:1 with $86.3 \%$ oil adsorbed or $0.87 \mathrm{~mL}$ oil per gram zeolite. Enrichment of zeolite with Bacillus subtilis improved the adsorbed oil by the mineral.
\end{abstract}

\section{Keywords}

Bayah Zeolite, Oil Adsorption, Sea Water Pollution, Molecular Sieve

\section{Introduction}

Environmental disturbance caused by crude oil pollution has been reported almost all over the world either on agricultural land or marine environment. Pe- 
troleum products and their related derivatives become one of the major sources of environmental pollution. During its processing starting from extraction to storage, crude oil may be discharged into the environment resulting in pollution of the ecosystem. As the impacts to the environments are considerably extensive, from which the oil derivatives have adverse effects on the ecosystems including soils and water, the effort to search for effective technique and new materials for the removal of such substances from contaminated sites is considered to be very highly important [1].

Numerous efforts have been done to remove crude oil spill polluting water media, including mechanical, biological, chemical and adsorption methods. These include the use of minerals like zeolite with strong characteristics as a molecular sieve, both natural and synthetic [2] [3] [4] [5] and various agricultural wastes with high adsorbent properties like sugarcane bagasse and rice hull [6], corncobs [7], banana peels [8] as well biodegradation and bioaugmentation [9], and also natural rubber/reduced graphene composite [10]. Nevertheless, the use of zeolite is most widely reported in the effort to remove oil spill. The synthetic zeolite used includes those derived from fly ash, whereas the natural one is that with clinoptilolite mineral in dominance.

Due to hydrophobic characteristic of the oil in water, oil removal from sea water is somewhat different to that found in oil-polluted soil due to hydrophobic characteristic of the oil in water. When oil spill took place at ocean, then it would be more difficult to handle as the oil will drift away and spread by time. Therefore, it is very important to apply such adsorbent capable of adsorbing oil very fast in a significant volume and hold the oil for a considerably long period. Protecting marine life from pollution caused by accidental spoiled crude oil becomes an urgent issue now. Thus, quick actions should be executed to avoid further widespread impacts. One of these actions is the cleaning-up process, which requires pumping, skimming, and storing the contaminated seawater. This operation requires deep knowledge of the physical and chemical proprieties of pollutant fluid that would help in calculating the power requirements for the cleaning-up process. In term of microbial bioremediation technology, global patent data show that Pseudomonas sp., Bacillus sp., and Rhodococcus sp. are the top three active ingredients [11].

The use of different zeolite types to refine some pollutant oils has been widely reported as described above. However, a natural zeolite from Bayah, Banten, Indonesia, has been known as a clinoptilolite zeolite with various use including soil amendment, feeds, and water purification [12] as well as potential greenhouse gas sequestration on peat soils [13], but not yet as oil spill adsorbent. Therefore, the present study reports the potential application of this material to be used as crude oil adsorbent, especially the one that pollutes sea water.

\section{Materials and Methods}

\subsection{Physico-Chemical Properties}

A 100-mesh zeolite originating from Bayah, Banten, Indonesia was used in this 
experiment and subjected to selected physico-chemical analyses. Pore structure including specific surface area, pore volume, and average pore diameter was determined based on $\mathrm{N}_{2}$-sorption analyses [14]. Chemical analyses performed including $\mathrm{pH}$, cation exchange capacity (CEC), silica, aluminum, calcium, sodium, and potassium elemental analyses by using standard laboratory analyses outlined by SNI 13-3494-1994 (ICS 73.080). Chemical data analyses of the crude oil samples were provided by Indonesia Research Institute of Oil and Gas (Lemigas) Jakarta.

\subsection{Mineralogical Characteristics}

Mineralogical composition of zeolite powder was determined by using $\mathrm{x}$-ray diffraction (XRD) analysis by running at $0^{\circ}-30^{\circ}$ 2-theta with $\mathrm{CuKa}$ at the Research Institute for Mineral and Coal (Tekmira) Bandung. Identification of the mineral present was carried out by using major intensive peak characterizing the mineral [15].

\subsection{Adsorption Capacity}

Adsorption capacity analyses of the Bayah zeolite was performed by using $\mathrm{CO}_{2}$ and $\mathrm{CH}_{4}$ adsorption analyses at Chemical Engineering Department, University of Gadjah Mada, Yogyakarta, employing gas adsorption/desorption isotherm by using Quanta chrome Instruments version 11.03.

\subsection{Experimental Design}

Laboratory experiments were carried out by reacting various ratios of crude oil to zeolite powder with and without microbial enrichment into a $250-\mathrm{mL}$ jar containing Java Sea seawater $(3.7 \% \mathrm{NaCl}$ and $\mathrm{pH}$ 6.7). The oil: zeolite ratio tested were 50\% (P1), $100(\mathrm{P} 2), 200(\mathrm{P} 3)$ and $400(\mathrm{P} 4) \%(\mathrm{v} / \mathrm{w})$ with constant weight of zeolite $(13 \mathrm{~g})$ and various oil volume $(6.5 \mathrm{~mL}-52 \mathrm{~mL})$ and observed for seven days at room temperature. The observations were any change of the oil-zeolite flocculates, volume of oil adsorbed, weight of zeolite forming the flocculates, and supporting evidences from microscopic observation. Each treatment had three replicates. The microbes used for zeolite enrichment was Bacillus subtilis. which have been identified before as hydrocarbon consuming bacterium. This bacterium was lodged in Microbiology and Environmental Laboratory of Indonesian Research Institute for Biotechnology and Bioindustry (IRIBB). As a source of inoculum, B. subtilis was grown on Luria Broth (LB) medium consisting of $(\mathrm{g} / \mathrm{L}): 0.5 \mathrm{~g}$ sodium chloride, $10 \mathrm{~g}$ tryptone, and $5 \mathrm{~g}$ yeast extract. The liquid culture was incubated at $30^{\circ} \mathrm{C}$ in a rotating shaker at $200 \mathrm{rpm}$ for 48 hours. After the incubation period, several inoculum concentrations, i.e. $5 \%, 7.5 \%$, and $10 \%(\mathrm{v} / \mathrm{w})$ were employed by spraying the Luria Broth medium containing fresh culture of the bacterium. Observations made were similar to those experiments without microbial inoculation.

\section{Results and Discussion}

\subsection{Properties of Zeolite and Crude Oil}

Data obtained from $\mathrm{N}_{2}$-adsorption and chemical analyses of the Bayah zeolite 
used in this experiment are presented in Table 1, whereas chemical data of the crude oil are shown in Table 2.

Based on XRD analysis the Bayah zeolite consists of clinoptilolite (75\%) with other minerals such as mordenite and quarts present as accessory minerals (Figure 1). Most application of this mineral in Indonesia was reported focused on agricultural sector especially in soil amendment and fertilizer industries [16]. Based on these characteristics, the opinion that such mineral has a great potential as adsorbent of greenhouse gas sequestration at peat land area especially for oil palm cultivation [13]. Employing this evidence and supported also by previous studies reported by others [3] [4] [9] [17] [18], this particular mineral originated from Bayah was considered to be potential as oil spill adsorbent.

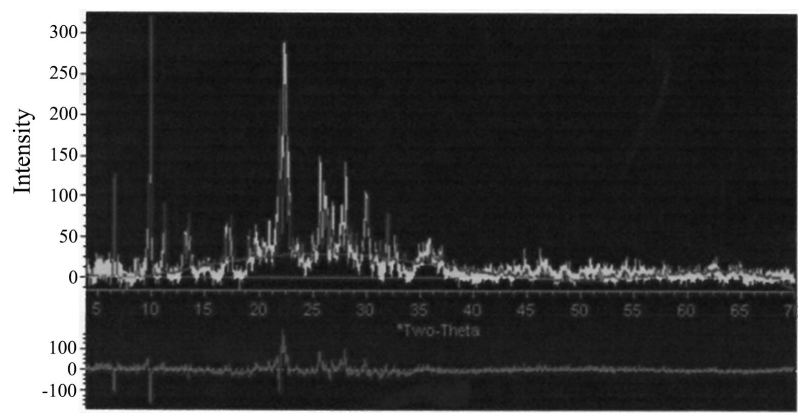

(a)

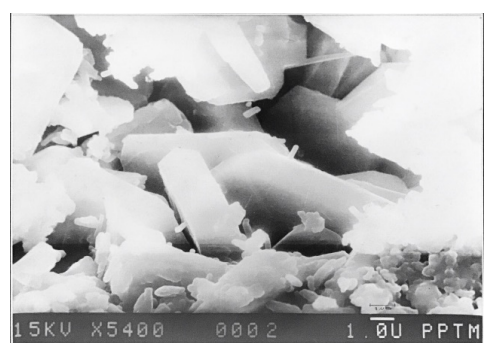

(a)

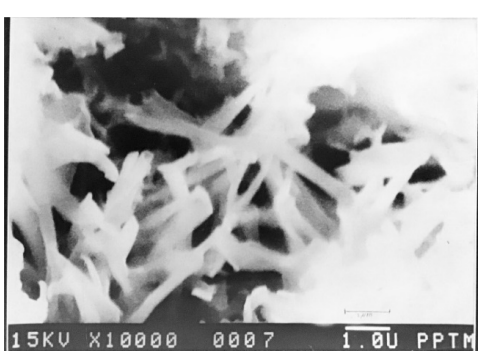

(b)

Figure 1. X-Ray Diffractogram (a) and Scanning Electron Microscopes (b) of Bayah zeolite indicating the dominant mineral of clinoptilolite.

Table 1. Physico-chemical characteristics of the Bayah zeolite.

\begin{tabular}{cc}
\hline Properties, Unit & Values \\
\hline Specific Surface Area, $\mathrm{m}^{2} / \mathrm{g}$ & 24.31 \\
Pore Volume, $\mathrm{cm}^{3} / \mathrm{g}$ & 0.079 \\
Average Pore Diameter, $\mathrm{nm}$ & 12.98 \\
$\mathrm{SiO}_{2}, \%$ & 71.10 \\
$\mathrm{Al}_{2} \mathrm{O}_{3}, \%$ & 11.46 \\
$\mathrm{Na}_{2} \mathrm{O}, \%$ & 0.14 \\
$\mathrm{CaO}, \%$ & 2.19 \\
$\mathrm{~K}_{2} \mathrm{O}, \%$ & 0.74 \\
$\mathrm{CEC}, \mathrm{meq} / 100 \mathrm{~g}$ & 167.19 \\
Moisture Content, \% & 3.81 \\
Loss of Ignition, \% & 11.88 \\
\hline
\end{tabular}


Table 2. Chemical data of crude oil used in the experiment.

\begin{tabular}{ccc}
\hline Properties, Unit & Values & Method \\
\hline Density at $15^{\circ} \mathrm{C}, \mathrm{kg} / \mathrm{m}^{3}$ & 931.0 & ASTM D 4052 \\
Heat of Combustion (GHV), BTU/lb & 18,972 & ASTM D 240 \\
Ash Content, \% wt & 0.007 & ASTM D 482 \\
Water Content, \% vol & 0.5 & ASTM D 4006 \\
$\mathrm{C}, \% \mathrm{wt}$ & 86.11 & ASTM D 5291 \\
$\mathrm{H}, \% \mathrm{wt}$ & 12.07 & ASTM D 5291 \\
$\mathrm{N}, \% \mathrm{wt}$ & 0.2550 & ASTM D 5291 \\
$\mathrm{S}, \% \mathrm{wt}$ & 0.2121 & ASTM D 4294 \\
\hline
\end{tabular}

\subsection{Effect of Zeolite-Oil Ratio on Crude Oil Removal}

Figure 2 shows the hydrophobicity nature of crude oil staying at the surface of sea water containing $3.7 \% \mathrm{NaCl}$ and $\mathrm{pH}$ of 6.7 . The addition of zeolite powder to the crude oil promoted flocculation resulting in the formation of zeolite-oil mixture and sedimented instantly (Figure 3 ). The flocculate remained stable during seven days of incubation.

Table 3 shows the effect of selected ratios of oil-zeolite on the capability of the mineral in adsorbing the oil. It is indicative statistically that 1:1 ratio of oil to the mineral provided the highest percentage of oil adsorbed by zeolite (86.28\%) compared to the other treatment with a lower value, i.e. $48.47 \%$ (P1), $47.30 \%$ (P3), and $24.11 \%(\mathrm{P} 4)$. In contrast, almost all zeolite added was flocculated and sedimented in zeolite-oil mixture $(95.99 \%$ - 98.56\%) leaving a smaller quantity in dispersed form $(1.44 \%-4.01 \%)$.

Figure 4 shows the relationship between oil-zeolite ratios and the ability of the mineral to adsorb the oil. Based on the equation, the optimum oil-zeolite ratio is reached at $94.1 \%$. This means that a ton of 100 -mesh zeolite could adsorb 0.94 cubic meters spoiled oil. However, the economic value of this technique should take into accounts the price of the mineral and the value of environmental impact created by the spoiled oil.

\subsection{Effects of Microbially Enriched Zeolite on Crude Oil Removal}

The effect of B. subtilis addition at different concentration on zeolite significantly correlated with the oil volume adsorbed by the mineral (Figure 5). Based on the equation, it is indicative that the bacterium identified as hydrocarbon consuming isolate reached its maximum effect at $2.07 \%(\mathrm{v} / \mathrm{w})$ concentration with $88.35 \%(\mathrm{v} / \mathrm{w})$ oil adsorbed. As reported by [11], B. subtilis was among the top three most common microbe patented for microbial bioremediation of oil contaminated seawater. The reason is that this bacterium has been recognized to be able of consuming hydrocarbon substance as source of energy. Improving the capacity of oil adsorption by bacterial addition is suspected related to the increase of surface area of the mineral upon microbial enrichment. Our data (not shown here) indicated that specific surface area of zeolite and zeolite + B. subtilis were 23.41 and $34.85 \mathrm{~m}^{2} / \mathrm{g}$, respectively, with a smaller pore diameter size (10.32 
$\mathrm{nm})$ of the later compared to the former $(12.98 \mathrm{~nm})$ and improved pore volume by $23.3 \%\left(0.073\right.$ vs $\left.0.090 \mathrm{~cm}^{3} / \mathrm{g}\right)$. However, this interesting phenomenon needs further study to determine the role of bacterium in improving zeolite characteristics as oil adsorbent.

Table 3. The effect of selected ratios of oil-zeolite on the capability of the mineral in adsorbing the oil.

\begin{tabular}{cccc}
\hline $\begin{array}{c}\text { Ratio Oil to Zeolite } \\
(\% \mathrm{v} / \mathrm{w})\end{array}$ & $\begin{array}{c}\text { Adsorbed Oil } \\
(\% \mathrm{v} / \mathrm{v})\end{array}$ & $\begin{array}{c}\text { Sedimented Zeolite } \\
(\% \mathrm{w} / \mathrm{w})\end{array}$ & $\begin{array}{c}\text { Zeolite Adsorption } \\
\text { Effectiveness }(\mathrm{ml} / \mathrm{g})\end{array}$ \\
\hline 50 & $53.26 \mathrm{~b}^{1)}$ & $98.23 \mathrm{ab}$ & $0.25 \mathrm{c}$ \\
100 & $86.84 \mathrm{a}$ & $98.56 \mathrm{a}$ & $0.88 \mathrm{~b}$ \\
200 & $50.12 \mathrm{~b}$ & $97.29 \mathrm{c}$ & $1.03 \mathrm{ab}$ \\
400 & $26.21 \mathrm{c}$ & $97.69 \mathrm{bc}$ & $1.07 \mathrm{a}$ \\
CV (\%) & 23.0 & 0.3 & 12.1 \\
\hline
\end{tabular}

${ }^{1)}$ Figures followed by the letter(s) in the same column are not significantly different according to Duncan's Multiple Range Test at $\mathrm{P}<5 \%$.

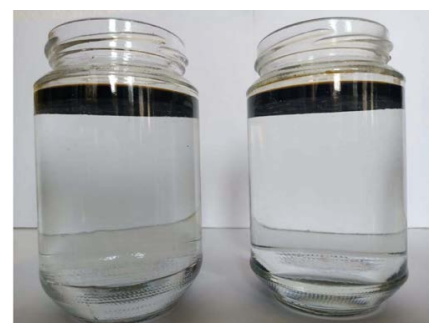

Figure 2. Strong hydrophobicity of crude oil to sea water. Dark color on the surface is crude oil spills.

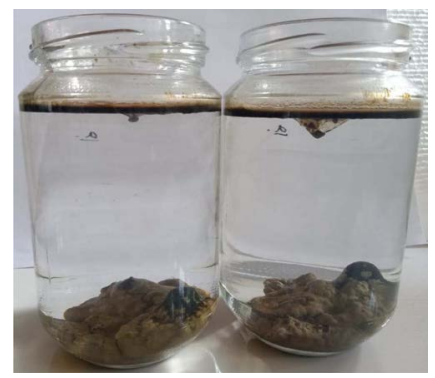

Figure 3. Instant flocculation of crude oil by zeolite observed after seven days of incubation.

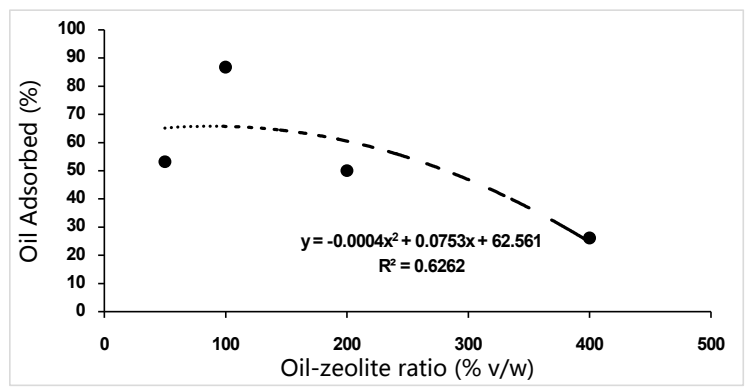

Figure 4. Relationships between oil-zeolite ratios and relative amount of oil adsorbed. 


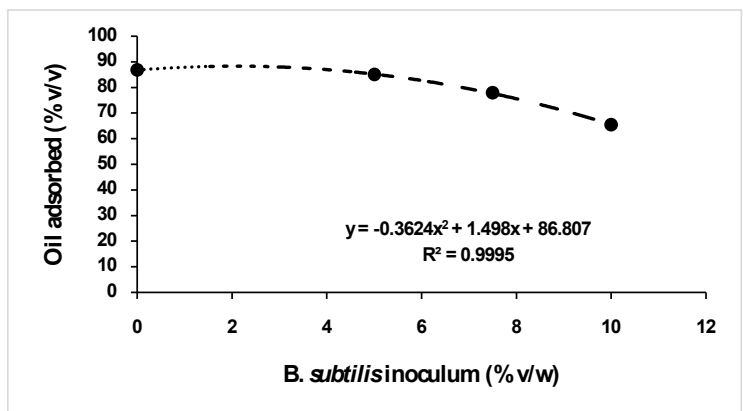

Figure 5. Effect of bacterial inoculum (B. subtilis) addition on the spilled-oil adsorbed.

\section{Conclusion}

Bayah clinoptilolitic zeolite has been shown to have highly potential characteristics as a sorbent for spoiled oil in seawater. Addition of a 100-mesh powder at $1: 2(\mathrm{w} / \mathrm{v})$ ratio could adsorb the oil up to more than $86 \%$. The addition of zeolite to oil spills in seawater promoted a stable flocculation. Oil adsorbing capacity improved by the addition of a bacterial inoculum B. subtilis. As this study was carried out at laboratory conditions, further study is required to confirm the results especially under field condition.

\section{Acknowledgements}

The authors wish to thank to PT Minerindo Trifa Buana and the Indonesia Research Institute of Oil and Gas (Lemigas), Jakarta for their valuable supports and provision of experiment materials.

\section{Conflicts of Interest}

The authors declare no conflicts of interest regarding the publication of this paper.

\section{References}

[1] Bandura, L., Woszuk, A., Kolodynska, D. and Franus, W. (2017) Application of Mineral Sorbents for Removal of Petroleum Substances: A Review. Minerals, 7, 1-25. https://doi.org/10.3390/min7030037

[2] Pathak, C. and Srivastava, V.K. (2012) Oil-Water Separation Using Fly Ash Zeolite Treatment. International Journal of Current Research and Review, 4, 155-167. http://www.ijrrr.com

[3] Bandura, L., Panek, R. and Franus, W. (2014) The Use of Clinoptilolite and Synthetic Zeolites for Removal of Petroleum Substances. http://ena.lp.edu.ua

[4] Bandura, L., Franus, M., Jozefaciuk, G. and Franus, W. (2015) Synthetic Zeolites from Fly Ash as Effective Mineral Sorbents for Land-Based Petroleum Spills Cleanup. Fuel, 147, 100-107. https://doi.org/10.1016/j.fuel.2015.01.067

[5] Gao, P., Zhang, Y. and Zhao, L. (2016) Synthetic Zeolites Derived from Fly Ash as Effective Mineral Sorbents for Diesel Fuel Spill Remediation. Clays and Clay Minerals, 64, 552-559. https://doi.org/10.1346/CCMN.2016.064035

[6] Bayat, A., Alghamiri, S., Moheb, A. and Vakilli-Nezhaad, G. (2005) Oil Spill Clean 
Up from Seawater by Sorbent Materials. Chemical Engineering \& Technology, 28, 1525-1528. https://doi.org/10.1002/ceat.200407083

[7] Nwadiogbu, J.O., Ajiwe, V.I.E. and Okoye, P.A.C. (2016) Removal of Crude Oil from Aqueous Medium by Sorption on Hydrophobic Corncobs: Equilibrium and Kinetic Studies. Journal of Taibah University for Science, 10, 56-63. https://doi.org/10.1016/j.jtusci.2015.03.014

[8] El-Din, G.A, Amer, A.A., Malsh, G. and Hussein, M. (2018) Study on the Use of Banana Peels for Oil Spill Removal. Alexandria Engineering Journal, 57, 2061-2068. https://doi.org/10.1016/j.aej.2017.05.020

[9] Kuran, P., Trogi, J., Novakova, J., Pilarova, V., Danova, P., Pavlorkova, J., Kozler, J., Novak, F. and Popelka, J. (2014) Biodegradation of Spilled Diesel Fuel in Agricultural Soil: Effect of Humates, Zeolite, and Bioaugmentation. The Scientific World Journal, 2014, Article ID: 642427. https://doi.org/10.1155/2014/642427

[10] Songsaeng, S., Thamyongkit, P. and Poompradub, S. (2019) Natural Rubber/Reduced-Graphene Oxide Composite Materials: Morphological and Oil Adsorption Properties for Treatment of Oil Spills. Journal of Advanced Research, 20, 79-89. https://doi.org/10.1016/j.jare.2019.05.007

[11] Villela, H.D.M., Peixoto, R.S., Soriano, A.U. and Carmo, F.L. (2019) Microbial Bioremediation of Oil Contaminated Seawater: A Survey of Patemt Deposits and the Characterization of the Top General Applied. Science of the Total Environment, 20, 743-758. https://doi.org/10.1016/j.scitotenv.2019.02.153

[12] Goenadi, D.H., Mustafa, A.B. and Santi, L.P. (2017) Bio-Organo-Chemical Fertilizers: A New Prospecting Technology for Improving Fertilizer Use Efficiency (FUE). IOP Conference Series. Earth and Environmental Science, 183, Article ID: 012011. https://doi.org/10.1088/1755-1315/183/1/012011

[13] Goenadi, D.H., Santi, L.P., Kalbuadi, D.N. and Nurtjahja, L.R. (2018) Zeo-Bio-Technology for Controling Peat Degradation. International Seminar " Understanding the Characteristics of Tropical Peat Ecosystem and the Efforts of Degraded Peat Restoration", Palangkaraya, 21-22 November 2018, 11 p.

[14] Zielinski, J.M. and Kettle, L. (2013) Physical Characterization: Surface Area and Porosity. http://www.intertek.com/chemicals

[15] Cullity, B.D. and Stock, S.R. (2001) Elements of X-Ray Diffraction. Prentice Hall, Upper Saddle River.

[16] Goenadi, D.H., Adiwiganda, Y.T. and Santi, L.P. (2005) Development Technology and Commercialization of EMAS (Enhancing Microbial Activity in the Soils) Biofertilizer. Forum for Nuclear Cooperation in Asia (FNCA) Biofertilizer Project. Issue No. 6 November 2005.

[17] Bani-Hani, E., Tawalbeh, M., Al-Othman, A. and Assad, M.E.H. (2018) Rheological Study on Seawater Contaminated with Oil Components. Polish Journal of Environmental Studies, 28, 2585-2591. https://doi.org/10.15244/pjoes/92121

[18] Shahrabadi, H., Sayareh, S. and Sarkadeh, H. (2017) Effect of Natural Zeolite-Pozzolan on Compressive Strength of Oil-Polluted Concrete Marine Structure. Civil Engineering Journal, 2, 623. https://doi.org/10.28991/cej-030985 